\title{
Partial Resistance to Fruit Necrosis Associated to Colletotrichum spp. among Arabic Coffee Genotypes
}

\author{
Gustavo Hiroshi Sera*, Tumoru Sera, Dhalton Shiguer Ito, José Alves de Azevedo, \\ Claudionor Ribeiro Filho and João Siqueira da Mata \\ Instituto Agronômico do Paraná; Área de Melhoramento e Genética Vegetal; Rod. Celso Garcia Cid, Km375; C.P. \\ 481; gustavosera@uol.com.br; tsera@iapar.br; 86001-970; Londrina-PR - Brasil
}

\begin{abstract}
The aim of this study was to evaluate the resistance to fruit necrosis associated to Colletotrichum spp. in $\underline{\text { Coffea }}$ arabica L.. Twenty-two arabic coffee genotypes were performed in a randomized block design, with three replications and ten plants per plot. They were evaluated for the variables fruit necrosis, luminosity index inside of the plant canopy and fruits per productive nodes of the plants. There was genetic variability for the resistance to fruit necrosis. Different partial resistance levels, varying from highly susceptible (score $=3.89$ ) to moderately resistant (score $=1.77$ ) were observed. The genotypes that presented moderate resistance were the cultivars IPR100, IPR-103, IPR-105 and IPR-108 and the coffee selection IAPAR-00023.
\end{abstract}

Key words: Antracnosis, Coffea arabica, coffee breeding, Colletotrichum gloeosporioides, cultivars

\section{INTRODUCTION}

In the coffee crop, many pathogens provoke great damages, as it is the case of the leaf rust. Fungus species of the genus Colletotrichum wasn't considered earlier as harmful to the brazilian coffee crop. However, recently, symptoms of necrosis in flowers, fruits, branches and leaves have been noticed associated to the Colletotrichum spp., which has been isolated from the coffee trees from Minas Gerais (Dorizzotto, 1993; Juliatti et al., 2000; Orozco-Miranda, 2003) and Paraná States (Silva et al., 2005). Paradela-Filho and Paradela (2001) reported that the causal agents of the coffee antracnosis in Brazil have been related as $C$. gloeosporioides and $C$. coffeanum.

The pathogenic forms of the Colletotrichum spp. have been found causing different symptoms. These occur from the base of plagiotropic branches and develop to the tip. The symptoms are: blackout and death of stipules; necrotic irregular spots on the leaves margins and defoliation; appearance of brown or black colour lesions on the branches; lesions in young plants, in conditions of nursery; necrotic lesions varying from brown colour and passing to black, in buds, flowers, pin-heads and fruits, provoking the death and the fall; and blackening and death of branches, where these two last the most important symptoms to the coffee tree. Only Colletotrichum spp. has been isolated from these symptoms. In rare cases of branches with die-back symptom and defoliation have been found in association Colletotrichum spp. with Phoma spp (ParadelaFilho et al., 2001).

These symptoms are being attributed by the attack of the complex Phomal Ascochyta (Matiello et al., 2005), and some researchers reported the highest

\footnotetext{
${ }^{*}$ Author for correspondence
} 
tolerance of Catucaí Amarelo 2SL genotype for this complex (Matiello et al., 2001; Krohling et al., 2004). Continuous periods of high humidity ( 7 to 10 days of rain) and temperatures around $22{ }^{\circ} \mathrm{C}$, are favorable to the development of the disease that pass from saprophytic phase to parasitic one (Paradela-Filho et al., 2001). Orozco-Miranda (2003) demonstrated that the micelial growth and sporulation of $C$. gloeosporioides isolates on maltagar medium were higher at $25^{\circ} \mathrm{C}$ than at $20^{\circ} \mathrm{C}$.

There are different strategies to reduce the damages of fruit necrosis associated to Colletotrichum spp. as described by ParadelaFilho et al. (2001). Little is known about chemical control. Another problem is that the critical periods to control are from the flowering until the expanded fruit stage. The chemical control doesn't coincide with the control period of other diseases such as the leaf rust, with consequent increases in the production costs. Thus, it is of great importance to develop the coffee cultivars with total or partial resistance. Many studies report about the coffee resistance to $C$. kahawae that occurs in Africa. The resistance to fruit necrosis has been described by Paradela-Filho et al. (2001) associated with Colletotrichum spp. in Brazil. Orozco-Miranda (2003) studied the resistance tests for Colletotrichum spp. in hypocotyls and green and ripe berries of coffees, which revealed several degrees of resistance. At Instituto Agronômico do Paraná (IAPAR), in Londrina, all the leaves, branches, flowers and necrosed fruits samples of coffee trees, with the symptoms described by Paradela-Filho et al. (2001), were identified as Colletotrichum spp. by Paradela-Filho (2004, personal information) and as C. gloeosporioides by Silva et al. (2005).

The aim of this study was to identify coffee genotypes $(C$. arabica L.) resistant to fruit necrosis associated to Colletotrichum spp. in field conditions.

\section{MATERIAL AND METHODS}

The field experiment was established on $18^{\text {th }}$ April 2001, at IAPAR conducted in spacing $2.5 \mathrm{~m}$ x 0.5 $\mathrm{m}$. The local altitude is $585 \mathrm{~m}$, with $21^{\circ} \mathrm{C}, 1610$ $\mathrm{mm}$ and $71 \%$ of annual averages temperature, precipitation and relative humidity of the air, respectively.

Twenty-two treatments were performed in a randomized block design, with three replications and ten plants per plot. These treatments were represented by the cultivars: Colombia, IPR-97, IPR-100, IPR-102, IPR-103，IPR-105，IPR-106 and Rubi MG-1192, being evaluated one progeny per cultivar with exception of the 'IPR-108' with three different progenies. Also was evaluated one treatment of each one of the coffee selections: $\mathrm{F}_{3}$ of 'IAPAR-59' x "Catucaí", $F_{4}$ of "Sarchimor" $x$ ("Etiópia $\mathrm{S}_{\mathrm{H}} 1$ " x "Catuaî́"), IAPAR-00015, $\mathrm{F}_{3}$ of 'IAPAR-59' x 'Mundo Novo', IAPAR-00023, IAPAR-00027, IAPAR-00025 and IAPAR-00031. 'IAPAR-59', 'Catuaí Vermelho IAC-99' and 'Tupi IAC 1669-33' were used as standard cultivars.

Field evaluations were performed in January 2004 on coffee with 3.3 years old and with fruits in pinheads and fruit expansion stages. The following variables were evaluated: fruit necrosis associated to Colletotrichum spp. ("COL"), luminosity index inside of the plant canopy ("LUM") and fruits per productive nodes ("FN").

To evaluate the "COL" scores from 1 to 5 were attributed based on the percentage of necrosed young fruits, where: $1=0$ to $5 \% ; 2=6$ to $10 \% ; 3$ $=11$ to $30 \% ; 4=31$ to $50 \%$; and $5=51$ to 100 $\%$.

It was observed that plants with few fruits per productive nodes presented few necrosed fruits associated with Colletotrichum spp., even in highly susceptible coffee. For this, the average fruits amount per productive nodes ("FN") of the better productive branches of the plants were evaluated, following a score scale from 1 to 5, where: $1=0$ to 3 fruits/ node; $2=4$ to 7 fruits/ node; $3=8$ to 11 fruits/ node; $4=12$ to 15 fruits/ node; and $5=$ more than 15 fruits/ node. Only plants with FN scores 3 or more were considered in the evaluations of the variable COL.

The evaluation of the luminosity index inside the plant canopy ("L") was visual and followed the scores from 1 to 5 , where score 1 represented very closed plants and with few luminosity inside of the canopy, where it was very difficult to observe the fruits or the reproductive structures that were inside the canopy and score 5 represented plants with high incidence of light inside the canopy, where it was possible to observe clearly the reproductive structures inside of the canopy. This parameter was evaluated to prevent errors in the fruit necrosis evaluation. The incidence of this seemed to increase in coffee trees with lower luminosity inside the canopy (Sera et al., 2004), and consequently with higher relative humidity of 
the air for the development of fungus. Thus, susceptible coffee with high incidence of light inside the canopy could present false resistance reaction in a similar way that it occurred in coffee trees with few fruits per node.

The Cochran's test (Gmax) was done to verify the homogeneity variances of the evaluations by scores. Simple linear regression coefficients (b) between the neperian logarithm of the means and the neperian logarithm of the variances were estimated to indicate the better transformations. For variable "COL." the $\log X$ transformation was used and for "LUM" and "FN" variables, it was $\sqrt{\mathrm{x}}$. The statistical program Genes (Cruz, 2001) was used for the analysis of variance at the level of mean of the plots. The Scott-Knott test was used to compare the means. The genotypic determination coefficient of the traits was estimated.

\section{RESULTS AND DISCUSSION}

The Cochran's test indicated that the variances were homogeneous. The experimental variation coefficient of the "COL.", "LUM" and "FN" were $14.6,12.8$ and $8.3 \%$, respectively, indicating good experimental precision for the three evaluated traits. The genotypic determination coefficient for the fruit necrosis variable was 0.86 , indicating high genetic variability among these genotypes, with great possibility of success in the selection for this variable.

By the test of means, it was possible to separate the treatments in four resistance levels (a, b, c and d), statistically different at $10 \%$ of probability, where four genotypes were considered highly susceptibles or HS (a), eight susceptibles or S (b), eight moderately susceptibles or MS (c) and five moderately resistants or MR (d) (Table 1).

Table 1 - Mean scores of the cultivars and coffee selections evaluated for the variables resistance to fruit necrosis associated to Colletotrichum spp. (COL), luminosity level index inside of the plant canopy (LUM), amount of fruits per productive nodes (FN), in January 2004, Londrina, PR, Brazil and resistance reactions (R).

\begin{tabular}{|c|c|c|c|c|c|}
\hline $\mathbf{T}$ & Genotype description & $\mathrm{COL}^{1}$ & $\mathbf{F N}^{1}$ & $\mathbf{L U M}^{\mathbf{1}}$ & $\mathbf{R}^{2}$ \\
\hline 8 & 'IPR-108' ('IAPAR-59’ x “Catucaî”) & $3.89 \mathrm{a}$ & $3,78 \mathrm{~b}$ & $2,97 \mathrm{a}$ & HS \\
\hline 19 & 'IPR-106’ (“Icatu”) & $3.67 \mathrm{a}$ & $3,07 \mathrm{c}$ & $1,42 \mathrm{c}$ & HS \\
\hline 5 & 'Colômbia' (“Catimor”) & $3.20 \mathrm{a}$ & $3,19 \mathrm{c}$ & $3,10 \mathrm{a}$ & HS \\
\hline 3 & IAPAR-00014 [ $\mathrm{F}_{4}$ of “Sarchimor" x ("Etiópia $\mathrm{S}_{\mathrm{H}} 1$ ” x “Catuaî')] & $3.19 \mathrm{a}$ & $3,49 \mathrm{c}$ & $2,60 \mathrm{~b}$ & HS \\
\hline 22 & ‘Tupi IAC 1669-33’ (“Sarchimor”) & $3.01 \mathrm{~b}$ & $4.09 \mathrm{a}$ & $2.61 \mathrm{~b}$ & $\mathrm{~S}$ \\
\hline 2 & IAPAR-00013 ( $\mathrm{F}_{3}$ of 'IAPAR-59' x “Catucaî”) & $2.98 \mathrm{~b}$ & $3.47 \mathrm{c}$ & $2.56 \mathrm{~b}$ & S \\
\hline 14 & IAPAR-00027 (“Catucaî’) & $2.98 \mathrm{~b}$ & $3.32 \mathrm{c}$ & $3.34 \mathrm{a}$ & S \\
\hline 1 & 'Rubi MG-1192’ & $2.67 \mathrm{~b}$ & $3.28 \mathrm{c}$ & $2.83 \mathrm{a}$ & $\mathrm{S}$ \\
\hline 4 & IAPAR-00015 (“Catucaî”) & $2.62 \mathrm{~b}$ & $3.52 \mathrm{c}$ & $2.68 \mathrm{~b}$ & S \\
\hline 9 & 'IPR-102’ (“Catucaî”) & $2.58 \mathrm{~b}$ & $3.53 \mathrm{c}$ & $2.31 \mathrm{~b}$ & S \\
\hline 7 & 'IPR-108' ('IAPAR-59’ x “Catucaî́) & $2.54 \mathrm{~b}$ & $3.63 \mathrm{~b}$ & $3.04 \mathrm{a}$ & $\mathrm{S}$ \\
\hline 20 & 'IAPAR-59’ (“Sarchimor”) & $2.44 \mathrm{c}$ & $3.58 \mathrm{~b}$ & $2.90 \mathrm{a}$ & MS \\
\hline 16 & IAPAR-00029 (F $F_{3}$ of 'IAPAR-59’ x “Mundo Novo”) & $2.31 \mathrm{c}$ & $3.61 \mathrm{~b}$ & $2.35 \mathrm{~b}$ & MS \\
\hline 21 & 'Catuaí Vermelho IAC-99’ & $2.30 \mathrm{c}$ & $3.14 \mathrm{c}$ & $2.83 \mathrm{a}$ & MS \\
\hline 15 & 'IPR-97’ (“Sarchimor”) & $2.30 \mathrm{c}$ & $3.67 \mathrm{~b}$ & $2.37 \mathrm{~b}$ & MS \\
\hline 12 & IAPAR-00025 (“Sarchimor”) & $2.21 \mathrm{c}$ & $3.70 \mathrm{~b}$ & $3.02 \mathrm{a}$ & MS \\
\hline 18 & IAPAR-00031 (“'Sarchimor”) & $2.14 \mathrm{c}$ & $3.39 \mathrm{c}$ & $2.57 \mathrm{~b}$ & MS \\
\hline 6 & 'IPR-108' ('IAPAR-59’ x “Catucaî”) & $2.00 \mathrm{~d}$ & $3.67 \mathrm{~b}$ & $2.71 \mathrm{~b}$ & MR \\
\hline 11 & 'IPR-105’ (“Catuaí $\mathrm{S}_{\mathrm{H}} 2, \mathrm{~S}_{\mathrm{H}} 3$ ”) & $1.90 \mathrm{~d}$ & $3.54 \mathrm{c}$ & $2.59 \mathrm{~b}$ & MR \\
\hline 17 & 'IPR-103’ (“Catucaî’) & $1.89 \mathrm{~d}$ & $4.36 \mathrm{a}$ & $2.46 \mathrm{~b}$ & MR \\
\hline 13 & 'IPR-100’ (“Catuaí $\mathrm{S}_{\mathrm{H}} 2, \mathrm{~S}_{\mathrm{H}} 3 ”$ ) & $1.84 \mathrm{~d}$ & $3.84 \mathrm{~b}$ & $2.59 \mathrm{~b}$ & MR \\
\hline 10 & IAPAR-00023 (“Catucaî”) & $1.77 \mathrm{~d}$ & $4.11 \mathrm{a}$ & $2.93 \mathrm{a}$ & MR \\
\hline
\end{tabular}

\footnotetext{
${ }^{1}$ Means followed by the same letter, did not differ by the Scott-Knott test at $10 \%$.
}

${ }^{2} \mathrm{HS}=$ highly susceptible; $\mathrm{S}=$ susceptile; $\mathrm{MS}=$ moderately susceptible; $\mathrm{MR}=$ moderately resistant. 
The IPR 100, IPR 103 and IPR 105 cultivars and one of the progenies that originated the 'IPR 108', all registered at Brazil's Ministry of Agriculture, and the IAPAR 00023 selection coffee ("Catucaî") were classified as MR. One of the progenies that originated the IPR 108 cultivar (treatment 7) was classified in the $\mathrm{S}$ group and one (treatment 8 ) in the HS group. The last one was the most susceptible progeny among all the evaluated treatments. Thus, segregation to fruit necrosis susceptibility occurred in the plants that originated the IPR 108 cultivar.

The standard cultivars IAPAR-59 and Catuaí Vermelho IAC-99 were classified as moderately susceptibles with 2.44 and 2.30 of mean score for the variable fruit necrosis, respectively. Other standard cultivar 'Tupi IAC 1669-33' was classified as susceptible with 3.01 average. Also, the IPR 97 cultivar and the coffee selections IAPAR 00025 ("Sarchimor"), IAPAR 00029 (F of 'IAPAR-59' x "Mundo Novo") and IAPAR 00031 ("Sarchimor") were classified as MS. 'IPR 102', 'Rubi MG-1192', "IAPAR - 00027" (“Catucaî"), "IAPAR 00013" (F F $_{3}$ 'IAPAR-59' x "Catucaî") and "IAPAR 00015" ("Catucaî") were classified as susceptibles. 'IPR 106', Colombia cultivar selection and "IAPAR 00014" were considered highly susceptibles. One of the 'IPR108' progenies (treatment 8) and the 'Colombia' selection presented high susceptibility, even with high luminosity index inside the canopy, indicating that higher severity of the necrosis could have occurred if they were with lower luminosity index.

Beyond these two cultivars, the genotypes "IAPAR-00027", "IAPAR-00025", "IAPAR00023", 'IAPAR-59', 'Rubi MG-1192' and 'Catuaí Vermelho IAC-99', all with high mean score for the variable LUM, also could present differentiated resistance reactions to fruit necrosis in coffee with lower luminosity index inside of the canopy. In genotypes "IAPAR-00014", 'Tupi IAC 1669-33', "IAPAR-00013", "IAPAR-00027", "IAPAR-00015" and 'IPR-102' high frequencies of resistant and susceptible plants was observed indicated that, possibly, they were segregating to the fruit necrosis resistance. The other treatments seemed to behave as not segregants, including the five genotypes moderately resistants (Table 2). Treatment 8 ('IPR-108') presented the highest frequency of plants with score 5 (28.6\%), whereas in treatments 6 and 7 of this cultivar didn't present plants with score 5, confirming the segregation hypothesis for the resistance among the progenies was occurring, needing selection for this cultivar (Table 2).

Resistance tests for C. gloeosporioides in hypocotyls and green and ripe berries used by Orozco Miranda (2003) were different in some aspects in relation to field evaluations done in this study, because: a) differences in the laboratory and field resistance; b) differences between the fruit resistance and hypocotyl resistance; c) segregation in the genotypes of the "Catucaî", "Catuaî" and of "Sarchimor"; d) causal agent of the fruit necrosis in Londrina and in Minas Gerais State can be differents; e) different isolates or races in Londrina and in Minas Gerais.

In the hypocotyls and green fruits tests OrozcoMiranda (2003) observed that 'Tupi IAC 1669-33' presented moderate resistance, while in this study, this cultivar revealed susceptibility.

The most coherent test used by Orozco-Miranda (2003) with the field evaluation was the resistance test in ripe berries, because the 'Catuaí Vermelho IAC 99' presented more resistance than 'Tupi IAC 1669-33'. Another similar result to this study was by Orozco Miranda (2003) who observed more susceptibility of the 'Rubi-MG 1192' than the 'Catuaí Vermelho IAC 99'. Also, Catucaí presented resistance and moderate resistance to several isolates of $C$. gloeosporioides in hypocotyls tests and was one of the most resistant in the green fruits test. Sera et al. (2003a) demonstrated in field evaluations that the $F_{2}$ population of 'IAPAR-59' $x$ "Catucaí" was more resistant to fruit necrosis than the $\mathrm{F}_{2}$ population of 'IAPAR-59' x "Mundo Novo", indicating that the resistance could have originated from "Catucaî" and the susceptibility originated from "Mundo Novo".

Many progenies of "Catucấ" or genotypes carrying alleles of the "Catucaî" were considered MR; however, some genotypes of this germplasm were classified as MS, S and HS groups. In plants derived from "Sarchimor" ('Villa Sarchi' x "Híbrido de Timor") segregation also occurred. 'Tupi IAC 1669-33' was susceptible, however, in this genotype the segregation can be occurring because was resistant to Minas Gerais's $C$. gloeosporioides isolates tested by Orozco Miranda (2003) in hypocotyls and green fruits.

The resistance to fruit necrosis could be derived from Coffea canephora Pierre, as indicated by 
"Catucaî" and "Sarchimor" resistant progenies in this study. Progenies of these germplasms were also resistants to C. gloeosporioides (OrozcoMiranda, 2003). Van der Vossen and Walyaro (1980) reported that probably the resistance of the "Hibrido de Timor" to C. kahawae originated from C. canephora.
In this experiment, none of the plants evaluated with "FN" score 3 or more (good frutification) presented the absence of the symptoms or complete resistance, indicating the partial resistance of these genotypes.

Table 2 - Frequency of the differents scores of the variable fruit necrosis (COL) in arabic coffee genotypes evaluated in Londrina, PR, Brazil.

\begin{tabular}{|c|c|c|c|c|c|c|}
\hline \multirow[t]{2}{*}{$\mathbf{T}^{1}$} & \multirow{2}{*}{ Genotype description } & \multicolumn{5}{|c|}{ Scores frequency (\%) of the variable COL } \\
\hline & & 1 & 2 & 3 & 4 & 5 \\
\hline 8 & ‘IPR-108' ('IAPAR-59’ x “Catucaî”) & 3.6 & 7.1 & 14.3 & 46.4 & 28.6 \\
\hline 19 & 'IPR-106’ (“Icatu”) & 8.3 & 0 & 50.0 & 33.3 & 8.4 \\
\hline 5 & 'Colômbia' (“Catimor”) & 0 & 11.5 & 57.7 & 30.8 & 0 \\
\hline 3 & $\begin{array}{c}\text { IAPAR-00014 [F “"Sarchimor" x (“Etiópia } \\
\text { S }_{\mathrm{H}} 1 \text { " x "Catuaî")] }\end{array}$ & 10.3 & 10.3 & 41.5 & 27.6 & 10.3 \\
\hline 22 & ‘Tupi IAC 1669-33’ (“Sarchimor”) & 17.2 & 3.4 & 51.8 & 17.2 & 10.4 \\
\hline 2 & IAPAR-00013 (F F $_{3}$ of 'IAPAR-59’ x “Catucaî”) & 0 & 30.8 & 46.2 & 19.2 & 3.8 \\
\hline 14 & IAPAR-00027 (“Catucaî”) & 0 & 34.6 & 42.4 & 19.2 & 3.8 \\
\hline 1 & 'Rubi MG-1192' & 0 & 38.8 & 55.6 & 5.6 & 0 \\
\hline 4 & IAPAR-00015 (“Catucaî”) & 8.0 & 44.0 & 32.0 & 12.0 & 4.0 \\
\hline 9 & 'IPR-102’ (“Catucaî”) & 10.7 & 35.7 & 39.3 & 10.7 & 3.6 \\
\hline 7 & 'IPR-108' ('IAPAR-59’ x “Catucaî”') & 0 & 64.7 & 29.4 & 5.9 & 0 \\
\hline 20 & 'IAPAR-59’ (“Sarchimor”) & 14.1 & 32.1 & 51.2 & 2.6 & 0 \\
\hline 16 & $\begin{array}{c}\text { IAPAR-00029 (F } \text { F }_{3} \text { of 'IAPAR-59' x “Mundo } \\
\text { Novo") }\end{array}$ & 18.6 & 40.7 & 29.6 & 11.1 & 0 \\
\hline 21 & ‘Catuaí Vermelho IAC-99’ & 4.2 & 70.8 & 25.0 & 0 & 0 \\
\hline 15 & 'IPR-97’ (“Sarchimor”) & 18.6 & 33.3 & 48.1 & 0 & 0 \\
\hline 12 & IAPAR-00025 (“Sarchimor”) & 12.0 & 56.0 & 32.0 & 0 & 0 \\
\hline 18 & IAPAR-00031 (“Sarchimor”) & 14.3 & 60.7 & 21.4 & 3.6 & 0 \\
\hline 6 & 'IPR-108' ('IAPAR-59’ x “Catucaî”') & 20.8 & 62.5 & 12.5 & 4.2 & 0 \\
\hline 11 & 'IPR-105’ (“Catuaí $\mathrm{S}_{\mathrm{H}} 2, \mathrm{~S}_{\mathrm{H}} 3$ 3”) & 22.2 & 66.7 & 11.1 & 0 & 0 \\
\hline 17 & 'IPR-103’ (“Catucaî”) & 46.4 & 17.9 & 32.1 & 3.6 & 0 \\
\hline 13 & 'IPR-100” (“Catuaí $\mathrm{S}_{\mathrm{H}} 2, \mathrm{~S}_{\mathrm{H}} 3$ ”) & 27.0 & 61.5 & 11.5 & 0 & 0 \\
\hline 10 & IAPAR-00023 (“Catucaî”) & 36.0 & 52.0 & 12.0 & 0 & 0 \\
\hline
\end{tabular}

${ }^{1}$ Genotypes in sequence decreasing basing on the mean score of fruit necrosis incidence.

The fruit necrosis associated to Colletotrichum spp. in coffees is highly influenced by the environment. Thus, for field evaluations, it is necessary to evaluate simultaneously variables such as "LUM" and "FN" to reduce the errors for the identification of resistant coffees. Sera et al. (2003b, 2004, 2005) noted that in less vigorous coffee most incidence of fruit necrosis and blackening and death of branches associated to Colletotrichum spp. occurred. Thus, vegetative vigor also must be evaluated. Equipments of high precision could be used as luximeter and 
hygrometer to measure, respectively, the light and the humidity inside the plant canopy to establish the field score for these traits.

It was possible that the resistance degrees found in coffee trees of this research could be different at other places or other years, therefore, the resistance to fruit necrosis was very influenced by the environment. Moreover, the resistance in field evaluations could be different from the laboratory evaluations due to the environmental effect. Orozco-Miranda (2003) found different resistance reactions in hypocotyls tests in relation to the tests with fruits in coffee inoculated with $C$. gloeosporioides isolates. Van der Graaff (1981) observed different resistance reactions to $C$. kahawae in different types of evaluations accomplished.

There could be possibility of the existence of different pathotypes of this fungus (Juliatti et al., 2000; Orozco-Miranda, 2003). Thus, in the same genotype different resistance reactions could occur. In hypocotyl tests, coffee genotypes presented different resistance degrees when inoculated with different isolates of $C$. gloeosporioides used by Orozco-Miranda (2003). Várzea et al. (2002) reported differential interaction among the cultivars and the isolates used in the resistance tests to $C$. kahawae in Coffea sp.. These researchers didn't identify any resistant coffee to all the isolates.

As the resistance to fruit necrosis seems to be specific to races, it is possible that the partial resistance is controlled by major genes. These genes can suffer by the action of minor genes of secondary effects, highly influenced by the environment. Studies done in Kenya (Van der Vossen and Walyaro, 1980) showed that the resistance to $C$. kahawae appeared to be controlled by major genes on three different loci in different varieties. Van der Graaff (1981) found continuous distribution for the resistance to C. kahawae and didn't observe the qualitative nature of the resistance genes. In the case of the resistance to fruit necrosis in the present work, the minor genes could be influenced by the vegetative vigor, nutrition and architecture increasing the relative humidity of the air inside the canopy. It was observed that coffee with less vegetative vigor (Sera et al., 2003b, 2004, 2005) and less luminosity index inside the canopy (Sera et al., 2004) presented more fruit necrosis associated to Colletotrichum spp.. In this work high determination genotypic coefficient $(b=0.86)$ was observed for the variable fruit necrosis. This indicated to be a trait of high heritability, indicating the hypothesis of one gene or few genes of resistance. The resistance to fruit necrosis could be due to different alleles of different genotypes, in a similar way that Van der Vossen and Walyaro (1980) observed for C. kahawae. Thus, the Catucaí's resistance alleles could be different to the Sarchimor's resistance alleles.

Moreover, probably, the resistance to fruit necrosis can be different of the resistances to buds, flowers, branches and leaves necrosis, which also are symptoms caused by Colletotrichum spp. (Paradela-Filho et al., 2001). Barbosa (2001) verified in maize crop that the correlation between stalk lesion area and leaf blighted area was not significant, evidencing that this two diseases, both provoked by $C$. graminicola, presented differents resistance mechanisms. Thus, the necrosis evaluation associated with Colletotrichum spp. must be accomplished in the different structures of the plant to verify differences between the resistance to fruit necrosis and the resistance to buds, flowers, branches and leaves necrosis. The low amount of fruits per productive node observed in some genotypes as in the case of Catuaí Vermelho IAC-99 and Rubi MG-1192 cultivars could be due to susceptibility of these to floral buds and flowers necrosis.

The better genotypes of this study must be evaluated for the resistance degrees and for the tolerance to fruit necrosis in controlled conditions by phytopathology laboratory methods, field evaluations, however, it would be necessary to evaluate branches, flowers and expanded fruits of same flowering time to reduce errors in the identification of resistance sources.

\section{CONCLUSIONS}

- There was genetic variability for the resistance to fruit necrosis associated to Colletotrichum spp. and the selection for this trait was relatively easy to the level of progenies due to the high genetic determinism $(b=0.86)$.

- The genotypes of Sarchimor and Catucaí germplasms were resistance sources for fruit necrosis associated to Colletotrichum spp.

- The genotypes with more resistance to fruit necrosis in field conditions were: IPR-100 and IPR-105 of "Catuaí $\mathrm{S}_{\mathrm{H}} 2, \mathrm{~S}_{\mathrm{H}} 3$ ", IPR-103 of 
"Catucaî" and IPR-108 of 'IAPAR-59' x "Catucaî" and the coffee selection IAPAR00023.

- The genotype IPR-108 segregated to fruit necrosis.

\section{ACKNOWLEDGEMENTS}

The authors thank the Instituto Agronômico do Paraná (IAPAR) and the Universidade Estadual de Londrina (UEL).

\section{RESUMO}

Diferentes espécies de fungo do gênero têm sido associadas a perdas na cafeicultura brasileira. $\mathrm{O}$ objetivo deste trabalho foi avaliar a resistência à necrose de frutos associada ao Colletotrichum spp. em Coffea arabica L.. Vinte e dois genótipos de café foram avaliados no delineamento em blocos ao acaso com três repetições e dez plantas por parcela. As avaliações foram realizadas no IAPAR, Londrina, em janeiro de 2004 para as variáveis necrose de frutos, índice de luminosidade dentro da copa da planta e frutos por nó produtivo. Existe variabilidade genética em cafeeiros arábicos para a resistência à necrose de frutos. Foi observado diferentes níveis de resistência parcial, variando de altamente suscetível (nota $=3,89$ ) a moderadamente resistente (nota $=1,77$ ). Os genótipos que apresentaram moderada resistência foram as cultivares IPR-100, IPR-103, IPR-105 e IPR-108 e a seleção de café IAPAR-00023.

\section{REFERENCES}

Barbosa, M. P. M. (2001), Variabilidade patogênica de Colletotrichum graminicola isolado de milho (Zea mays L.). MSc Thesis, Escola Superior de Agricultura Luiz de Queiroz, Piracicaba, Brazil.

Cruz, C. D. (2001), Programa Genes: versão Windows; aplicativo computacional em genética e estatística. Viçosa: UFV. 648p.

Dorizzotto, A. (1993), Caracterização morfológica e patogenicidade de Colletotrichum sp. associados a cafeeiros (Coffea arabica L.) em dois municípios de Minas Gerais. MSc Thesis, Escola Superior de Agricultura de Lavras, Brazil.
Juliatti, F. C.; Silva, C. C. N.; Filho, L. R. G. (2000), Estudos das características fisiológicas e genéticas de isolados de Colletotrichum spp. coletados em lavouras cafeeiras (Coffea arabica) de Minas Gerais. 1 - Testes de patogenicidade e análise molecular. Paper presented at $1^{\text {st }}$ Simpósio de Pesquisa dos Cafés do Brasil, Poços de Caldas, Minas Gerais, Brazil.

Krohling, C. A.; Matiello, J. B.; Almeida, S. R. (2004), Maior tolerância a Phomal Ascochyta em cafeeiros Catucaí 2SL em Marechal Floriano-ES. Paper presented at $30^{\text {th }}$ Congresso Brasileiro de Pesquisas Cafeeiras, São Lourenço, Minas Gerais, Brazil.

Matiello, J. B.; Almeida, S. R.; Krohling, C.; Brito, G. (2001), Adaptação de novas variedades de café em regiões cafeeiras de inverno úmido, na Bahia e Espírito Santo e provável tolerância ao complexo Phomal Ascochyta. Paper presented at $27^{\text {th }}$ Congresso Brasileiro de Pesquisas Cafeeiras, Uberaba, Minas Gerais, Brazil.

Matiello, J. B.; Guimarães, R. J.; Almeida, S. R.; Japiassú, L. B.; Paiva, R. N.; Garcia, A. W. F.; Carvalho, C. H. S. de. (2005), Phomal Ascochyta ataca severamente a florada neste ano. Coffea Revista de Tecnologia Cafeeira. ano 2, n. 8. p. 36-37.

Orozco-miranda, E. F. (2003), Caracterização morfológica, molecular, bioquímica e patogênica de isolados de Colletotrichum spp. associados ao cafeeiro em Minas Gerais e comparação com Colletotrichum kahawae. Doctoral Thesis, Universidade Federal de Lavras, Lavras, Brazil.

Paradela-filho, O.; Paradela, A. L. (2001), O complexo Colletotrichum - cafeeiro. In: Zambolim, L. (Ed.). Tecnologias de produção de café com qualidade. Viçosa: UFV, pp. 269-275.

Paradela-filho, O.; Paradela, A. L.; Thomaziello, R. A.; Ribeiro, I. J. A.; Sugimori, M. H.; Fazuoli, L. C. (2001), O complexo Colletotrichum do cafeeiro. Boletim Técnico IAC, Campinas, n. 191.

Sera, G. H.; Altéia, M. Z.; Sera, T.; Petek, M. R. (2003b), Avaliação e seleção de cafeeiros para resistência ao Colletotrichum spp. em germoplasma de café portador dos genes da 'IAPAR - 59'. Paper presented at Seminário Internacional do Agronegócio do Café na Amazônia, July 2002, Ji-Paraná, Rondônia, Brazil.

Sera, G. H.; Altéia, M. Z.; Sera, T.; Petek, M. R. (2003a), Correlação entre a ocorrência de Colletotrichum spp. com outras características agronômicas em cafeeiros (Coffea arabica L.) portadores de genes de $C$. canephora. Paper presented at $3^{\text {rd }}$ Simpósio de Pesquisa dos Cafés do Brasil, Porto Seguro, Bahia, Brazil.

Sera, G. H.; Altéia, M. Z.; Sera, T.; Petek, M. R.; Ito, D. S. (2005), Correlação entre a ocorrência de Colletotrichum spp. e outras características agronômicas em cafeeiros. Bragantia, Campinas, 64: $3,435-440$. 
Sera, G. H.; Ito, D. S.; Sera, T.; Petek, M. R.; Mata, J. S. da; Azevedo, J. A.; Doi, D. S.; Cotarelli, V. M. (2004), Associação da incidência de Colletotrichum spp. com características agronômicas em cafeeiros. SBPN Scientific Journal - Proceedings of the $12^{\text {th }}$ Encontro Nacional da SBPN, v. 8. p. 19.

Silva, M. R. L.; Meneguim, L.; Gonçalves, J. S.; Pistori, J. F.; Leite JR., R. P. (2005), Caracterização de Colletotrichum spp. associado ao cafeeiro no Estado do Paraná. Paper presented at $4^{\text {th }}$ Simpósio de Pesquisa dos Cafés do Brasil, Londrina, Paraná, Brazil.

Van der graaff, N. A. (1981), Selection of arabica coffee resistant to coffee berry disease in Ethiopia. Doctoral thesis, Wageningen, The Netherlands.
Van der Vossen, H. A. M.; Walyaro, D. J. A. (1980), Breeding for resistance to coffee berry disease in Coffea arabica L., 29, 777-791.

Várzea, V. M. P.; Silva, M. C. M. L.; Rodrigues JR., C. J. (2002), Resistência do cafeeiro à antracnose-dosfrutos-verdes. In: Zambolim, L. (Ed.). O estado da arte de tecnologias na produção de café. Viçosa: UFV, pp. 321-368.
Received: August 19, 2005; Revised: June 05, 2006; Accepted: March 20, 2007. 